\title{
A Cross-sectional Survey of the Clinical Manifestations and Underlying Illness of Cough
}

\author{
TAKEHIRO OTOSHI ${ }^{1}$, TATSUYA NAGANO ${ }^{1}$, YASUHIRO FUNADA ${ }^{2}$, \\ KAZUHIRO TAKENAKA ${ }^{2}$, HIROYUKI NAKATA ${ }^{2}$, HISASHI OHNISHI ${ }^{3}$, \\ TERUAKI NISHIUMA ${ }^{3}$, TAKEO NAKAJIMA ${ }^{4}$, TOSHIAKI KAGESHITA ${ }^{5}$, TAKAAKI TSUCHIYA ${ }^{5}$, \\ MASATSUGU YAMAMOTO ${ }^{1}$, KAZUYUKI KOBAYASHI ${ }^{1}$ and YOSHIHIRO NISHIMURA ${ }^{1}$ \\ ${ }^{1}$ Division of Respiratory Medicine, Department of Internal Medicine, \\ Kobe University Graduate School of Medicine, Kobe, Japan; \\ ${ }^{2}$ Department of Respiratory Disease, Takatsuki General Hospital, Takatsuki, Japan; \\ ${ }^{3}$ Department of Respiratory Medicine, Akashi Medical Center, Akashi, Japan; \\ ${ }^{4}$ Department of Respiratory Medicine, Kobe Rosai Hospital, Kobe, Japan; \\ ${ }^{5}$ Department of Respiratory Medicine, National Hospital Organization Kobe Medical Center, Kobe, Japan
}

\begin{abstract}
Aim: The aim of this study was to identify factors affecting the final diagnosis of cough. Materials and Methods: This study recruited 463 consecutive patients who visited five Japanese general hospitals due to cough from October 2006 to September 2007. Of these, 418 patients (90\%) who completed a questionnaire designed to acquire data regarding clinical manifestations of cough were included. Results: Most patients with bronchial asthma had cough with seasonal variation and wheezing. Patients with gastro esophageal reflux disease suffered from heartburn and cough without daily or seasonal variation. Cough associated with sinobronchial syndrome was only observed in females and was linked to increased sputum. Patients with whooping cough were bothered by cough interrupting sleep and talking. Patients with cardiogenic cough had exertional dyspnea. Conclusion: The specific items on our questionnaire relating to patient characteristics, complications, and triggers of cough, represent useful tools for diagnosing the primary disease producing cough.
\end{abstract}

Cough is one of the most common reasons for hospital visits (1) and has a substantial impact on quality of life (for

This article is freely accessible online.

Correspondence to: Tatsuya Nagano, MD, Ph.D., Division of Respiratory Medicine, Department of Internal Medicine, Kobe University Graduate School of Medicine, 7-5-1 Kusunokicho, Chuo-ku, Kobe, Hyogo 650-0017, Japan. Tel: +81 783825660, Fax: +81 783825661, e-mail: tnagano@med.kobe-u.ac.jp

Key Words: Cross-sectional survey, cough, bronchial asthma, cough-variant asthma, atopic cough. example, sleep disturbances or depression) and the use of healthcare resources (2-4). Cough is categorized according to its duration of symptoms: acute (0-2 weeks), sub-acute (37 weeks) and chronic (more than 8 weeks) (5). Previous studies have reported that the causes of acute and sub-acute cough are mostly acute respiratory infection and postinfection cough $(1,6)$, while the proportion of patients suffering from cough due to non-infectious diseases increases as the duration of cough increases (1). However, the causes of cough may vary in patients living in different geographical regions or among those of different ethnicities (7). While some existing reports focus on patients with chronic cough attending hospitals in Japan (8-11), very few studies have attempted to investigate the causes of cough among patients visiting hospitals with different types of cough (acute, sub-acute and chronic) (1). Moreover, little is known about the specific clinical manifestations of cough. The aim of this study was to clarify the clinical manifestations of cough, investigate the causative disorders involved, and identify factors affecting the final diagnosis of cough in an urban Japanese population.

\section{Materials and Methods}

Clinical institutions and participants. This was a cross-sectional survey performed between October 2006 and September 2007 at five general hospitals in Japan: Kobe University Hospital; Takatsuki General Hospital; Akashi Medical Center; Kobe Rosai Hospital and National Hospital Organization Kobe Medical Center. The study recruited 463 consecutive patients who made their first request for medical help in regard to their cough as outpatients of our five hospitals during the study period. Of these, 418 respondents answered our questionnaire, representing an overall return rate of $90 \%$. Questionnaires were handed out by hospital personnel with a 
standardized letter explaining the purpose of the study. Once completed, the patients returned the questionnaires to hospital personnel, who forwarded them to central office.

All patients received treatment based on an initial diagnosis made by chest physicians with over 10 years of experience in the management of patients with cough. Following treatment, final diagnoses of primary disease were made.

This survey was approved by the Institutional Review Board of Kobe University Hospital (approval number 180091).

Questionnaire. Our questionnaire was designed specifically for this project and featured four sections: (i) Personal data including patient age, gender, smoking status, pet and past medical history, including infantile asthma, allergic rhinitis, atopic dermatitis, chronic sinusitis and chronic cough; (ii) time characteristics of cough, including daily variation, seasonal variation and duration; (iii) complications of cough, including wheezing, increase of sputum, pharyngeal discomfort, heartburn, anxiety, frustration, insomnia and exertional dyspnea; and (iv) triggers of cough, including talking, cigarette smoke, house dust, meals and the common cold.

Diagnosis and treatment. Diagnoses of the primary diseases underlying cough were based on previously described criteria $(5,12$ 16), using the questionnaire, physical examination, blood tests, chest and sinus radiographs, pulmonary function, airway responsiveness, cough sensitivity tests and response to treatment. In brief, a diagnosis of gastroesophageal reflux disease (GERD) was made on the basis of a response to an 8 week-course of a proton-pump inhibitor or positive results from $24 \mathrm{~h}$ ambulatory esophageal $\mathrm{pH}$ monitoring. Diagnosis of cough variant asthma (CVA) was based on the following criteria: Cough which did not last longer than 3 weeks, without wheezing and non-audible on auscultation, and with symptomatic improvement following the use of inhaled $\beta 2$ agonists or sustained-release theophylline. Diagnosis of sinobronchial syndrome was made following a positive result on sinus images and an improvement of cough, as well as symptoms related to chronic sinusitis, with antibiotics. Diagnosis of atopic cough was made according to the following criteria: Non-productive cough lasting more than 3 weeks without wheezing or dyspnea, the presence of one or more findings indicative of atopy, a cough resistant to bronchodilator therapy, including a past history or complications of allergic diseases excluding asthma, peripheral blood eosinophilia, raised total IgE level in the serum, positive specific IgE antibody to aeroallergens, a positive allergen skin test or induced sputum eosinophilia with symptomatic improvement of coughing following treatment with an $\mathrm{H} 1$ blocker or inhaled corticosteroid. All of the patients with chronic cough had normal chest radiographs. Treatments included, inhaled corticosteroid, $\beta_{2}$ agonist, long-acting muscarinic antagonist, oral corticosteroid, theophylline, leukotriene antagonist, antibiotics, $\mathrm{H}_{1}$ blocker, $\mathrm{H}_{2}$ blocker, proton-pump inhibitor, antitussive and expectorant.

Statistical analysis. All data were entered into a pre-constructed Microsoft Excel sheet by two investigators. The entered data was checked by two randomly-selected Authors and by a plausibility test during descriptive data analysis. Pearson chi-squared test was used to assess difference in sensitivity and specificity.

Patient and public involvement. We were aware that patients with cough exhibit a variety of symptoms. Therefore, the patients with cough were consecutively involved in the study. This cross-sectional survey was performed in five of our hospitals and was approved by the
Table I. Patient characteristics.

\begin{tabular}{lc}
\hline Characteristic & $\mathrm{N}(\%)$ \\
\hline Age (years) (N=408) & \\
$0-19$ & $12(3)$ \\
$20-29$ & $73(18)$ \\
$30-39$ & $89(22)$ \\
$40-49$ & $44(10)$ \\
$50-59$ & $64(16)$ \\
$60-69$ & $62(15)$ \\
$70-79$ & $48(12)$ \\
$80+$ & $16(4)$ \\
Gender (N=410) & \\
Male & $188(46)$ \\
Female & $222(54)$ \\
Smoking status (N=408) & \\
Never & $241(59)$ \\
Ever & $54(13)$ \\
Current & $113(28)$ \\
Pet $(\mathrm{N}=418)$ & \\
None & $318(76)$ \\
Dog* & $59(14)$ \\
Cat* & $26(7)$ \\
Bird & $1(0)$ \\
Hamster* & $4(1)$ \\
Turtle* & $7(2)$ \\
Past history (N=418) & \\
None & \\
Infantile asthma* & $223(53)$ \\
Allergic rhinitis* & $21(5)$ \\
Atopic dermatitis* & $114(27)$ \\
Chronic sinusitis* & $30(7)$ \\
Chronic cough* & $31(7)$ \\
\hline & $85(20)$ \\
\hline
\end{tabular}

*Overlapping data.

Table II. Time characteristics of cough.

\begin{tabular}{lc}
\hline Characteristic & N (\%) \\
\hline Daily variation (N=418) & \\
Morning* & $81(19)$ \\
Daytime* & $43(10)$ \\
Evening* & $56(13)$ \\
Before bedtime* & $77(18)$ \\
Bedtime* & $77(18)$ \\
No daily variation & $250(60)$ \\
Seasonal variation (N=152) & \\
December-February (Winter)* & $19(13)$ \\
March-May (Spring)* & $8(5)$ \\
June-August (Summer) & $0(0)$ \\
September-November (Autumn)* & $5(3)$ \\
Seasonal changes & $2(1)$ \\
No seasonal variation & $123(81)$ \\
Duration (weeks) (N=220) & \\
0-2 (Acute) & $41(19)$ \\
3-7 (Sub-acute) & $82(37)$ \\
8+ (Chronic) & $97(44)$ \\
\hline
\end{tabular}

*Overlapping data. 
Table III. Complications of cough.

\begin{tabular}{lr}
\hline Complication* & $\mathrm{N}(\%)$ \\
\hline Wheezing (N=387) & $100(26)$ \\
Sputum increase (N=408) & $143(35)$ \\
Pharyngeal discomfort $(\mathrm{N}=404)$ & $86(21)$ \\
Heartburn (N=377) & $82(22)$ \\
Anxiety (N=407) & $60(15)$ \\
Frustration $(\mathrm{N}=401)$ & $48(12)$ \\
Insomnia $(\mathrm{N}=406)$ & $94(23)$ \\
Exertional dyspnea $(\mathrm{N}=380)$ & $48(13)$ \\
\hline
\end{tabular}

*Overlapping data.

Table IV. Triggers of cough.

\begin{tabular}{lr}
\hline Trigger* & $\mathrm{N}(\%)$ \\
\hline Talking $(\mathrm{N}=376)$ & $165(44)$ \\
Cigarette smoke $(\mathrm{N}=288)$ & $92(32)$ \\
House dust $(\mathrm{N}=340)$ & $126(37)$ \\
Meals $(\mathrm{N}=339)$ & $35(10)$ \\
Common cold $(\mathrm{N}=387)$ & $252(65)$ \\
\hline
\end{tabular}

*Overlapping data.

Table V. Diagnosis classified by duration of cough.

\begin{tabular}{lcccc}
\hline Diagnosis & Total, & Acute, & Sub-acute, & Chronic, \\
& N $(\%)$ & N (\%) & N (\%) \\
\hline Bronchial asthma & $30(14)$ & $1(3)$ & $11(14)$ & $18(20)$ \\
CVA* & $14(7)$ & $0(0)$ & $7(9)$ & $7(8)$ \\
Atopic cough & $2(1)$ & $0(0)$ & $1(1)$ & $1(1)$ \\
GERD & $3(1)$ & $0(0)$ & $0(0)$ & $3(3)$ \\
COPD & $6(3)$ & $0(0)$ & $0(0)$ & $6(7)$ \\
Sinobronchial syndrome* & $6(3)$ & $0(0)$ & $3(4)$ & $3(3)$ \\
ARI & $67(32)$ & $28(72)$ & $31(40)$ & $8(9)$ \\
Whooping cough & $1(1)$ & $1(3)$ & $0(0)$ & $0(0)$ \\
PIC & $67(32)$ & $7(18)$ & $22(28)$ & $38(42)$ \\
Lung cancer & $2(1)$ & $0(0)$ & $1(1)$ & $1(1)$ \\
Interstitial pneumonia & $6(3)$ & $2(5)$ & $1(1)$ & $3(3)$ \\
Cardiogenic cough & $2(1)$ & $0(0)$ & $2(3)$ & $0(0)$ \\
Other & $3(1)$ & $0(0)$ & $1(1)$ & $2(2)$ \\
Total, n & 207 & 39 & 78 & 90 \\
\hline
\end{tabular}

CVA, Cough variant asthma; GERD, gastro esophageal reflux disease; COPD, chronic obstructive lung disease; ARI, acute respiratory infection; PIC, post-infection cough. Sinobronchial syndrome included postnasal drip. Acute respiratory infection included common cold, influenza, acute tonsillitis, bronchiolitis, and pneumonitis. *Overlapping data.
Table VI. Treatment efficacy rates.

\begin{tabular}{|c|c|c|c|c|c|}
\hline Treatment* & Efficacy & $\begin{array}{l}\text { Total, } \\
\text { N (\%) }\end{array}$ & $\begin{array}{l}\text { Acute, } \mathrm{S} \\
\mathrm{N}(\%)\end{array}$ & $\begin{array}{c}\text { Sub-acute, } \\
\text { N (\%) }\end{array}$ & $\begin{array}{c}\text {, Chronic, } \\
\text { N }(\%)\end{array}$ \\
\hline \multirow[t]{4}{*}{ ICS } & Effective & $11(69)$ & $0(0)$ & $4(67)$ & $7(78)$ \\
\hline & Somewhat effective & $0(0)$ & $0(0)$ & $0(0)$ & $0(0)$ \\
\hline & Ineffective & $1(6)$ & $0(0)$ & $0(0)$ & $1(0)$ \\
\hline & Unknown & $4(25)$ & $0(0)$ & $2(33)$ & $2(22)$ \\
\hline \multirow[t]{4}{*}{$\beta 2$ Agonist } & Effective & $23(56)$ & $2(75)$ & $11(74)$ & $10(43)$ \\
\hline & Somewhat effective & $8(20)$ & $0(0)$ & $2(13)$ & $6(26)$ \\
\hline & Ineffective & $4(10)$ & $0(0)$ & $0(0)$ & $4(17)$ \\
\hline & Unknown & $6(14)$ & $1(25)$ & $2(13)$ & $3(13)$ \\
\hline \multirow[t]{4}{*}{ LAMA } & Effective & $0(0)$ & $0(0)$ & $0(0)$ & $0(0)$ \\
\hline & Somewhat effective & $0(0)$ & $0(0)$ & $0(0)$ & $0(0)$ \\
\hline & Ineffective & $1(100)$ & $0(0)$ & $0(0)$ & $1(100)$ \\
\hline & Unknown & $0(0)$ & $0(0)$ & $0(0)$ & $0(0)$ \\
\hline \multirow[t]{4}{*}{ OCS } & Effective & $2(100)$ & $0(0)$ & $1(100)$ & $1(100)$ \\
\hline & Somewhat effective & $0(0)$ & $0(0)$ & $0(0)$ & $0(0)$ \\
\hline & Ineffective & $0(0)$ & $0(0)$ & $0(0)$ & $0(0)$ \\
\hline & Unknown & $0(0)$ & $0(0)$ & $0(0)$ & $0(0)$ \\
\hline \multirow[t]{4}{*}{ Theophylline } & Effective & $5(56)$ & $2(100)$ & $1(33)$ & $2(50)$ \\
\hline & Somewhat effective & $2(22)$ & $0(0)$ & $1(33)$ & $1(25)$ \\
\hline & Ineffective & $1(11)$ & $0(0)$ & $0(0)$ & $1(25)$ \\
\hline & Unknown & $1(11)$ & $0(0)$ & $1(34)$ & $0(0)$ \\
\hline \multirow{4}{*}{$\begin{array}{l}\text { Leukotriene } \\
\text { antagonist }\end{array}$} & Effective & $2(25)$ & $0(0)$ & $2(67)$ & $0(0)$ \\
\hline & Somewhat effective & $4(50)$ & $0(0)$ & $1(33)$ & $3(60)$ \\
\hline & Ineffective & $1(12)$ & $0(0)$ & $0(0)$ & $1(20)$ \\
\hline & Unknown & $1(13)$ & $0(0)$ & $0(0)$ & $1(20)$ \\
\hline \multirow[t]{4}{*}{ Antibiotics } & Effective & $44(66)$ & $9(60)$ & $15(63)$ & $20(71)$ \\
\hline & Somewhat effective & $3(4)$ & $1(7)$ & $0(0)$ & $2(7)$ \\
\hline & Ineffective & $2(3)$ & $0(0)$ & $1(4)$ & $1(4)$ \\
\hline & Unknown & $18(27)$ & $5(33)$ & $8(33)$ & $5(18)$ \\
\hline \multirow[t]{4}{*}{ H1 Blocker } & Effective & $4(80)$ & $1(100)$ & $1(100)$ & $2(67)$ \\
\hline & Somewhat effective & $0(0)$ & $0(0)$ & $0(0)$ & $0(0)$ \\
\hline & Ineffective & $0(0)$ & $0(0)$ & $0(0)$ & $0(0)$ \\
\hline & Unknown & $1(20)$ & $0(0)$ & $0(0)$ & $1(33)$ \\
\hline \multirow[t]{4}{*}{ H2 Blocker } & Effective & $0(0)$ & $0(0)$ & $0(0)$ & $0(0)$ \\
\hline & Somewhat effective & $0(0)$ & $0(0)$ & $0(0)$ & $0(0)$ \\
\hline & Ineffective & $1(100)$ & $0(0)$ & $0(0)$ & $1(100)$ \\
\hline & Unknown & $0(0)$ & $0(0)$ & $0(0)$ & $0(0)$ \\
\hline \multirow[t]{4}{*}{ PPI } & Effective & $0(0)$ & $0(0)$ & $0(0)$ & $0(0)$ \\
\hline & Somewhat effective & $0(0)$ & $0(0)$ & $0(0)$ & $0(0)$ \\
\hline & Ineffective & $0(0)$ & $0(0)$ & $0(0)$ & $0(0)$ \\
\hline & Unknown & $2(100)$ & $0(0)$ & $0(0)$ & $2(100)$ \\
\hline \multirow[t]{4}{*}{ Antitussive } & Effective & $87(67)$ & $22(78)$ & $27(68)$ & $38(62)$ \\
\hline & Somewhat effective & $16(12)$ & $3(11)$ & $2(5)$ & $11(18)$ \\
\hline & Ineffective & $6(5)$ & $0(0)$ & $3(7)$ & $3(5)$ \\
\hline & Unknown & $20(16)$ & $3(11)$ & $8(20)$ & $9(15)$ \\
\hline \multirow[t]{4}{*}{ Expectorant } & Effective & $52(70)$ & $8(67)$ & $20(71)$ & $24(71)$ \\
\hline & Somewhat effective & $9(12)$ & $1(8)$ & $2(7)$ & $5(15)$ \\
\hline & Ineffective & $2(3)$ & $0(0)$ & $1(4)$ & $2(6)$ \\
\hline & Unknown & $11(15)$ & $3(25)$ & $5(18)$ & $3(8)$ \\
\hline Total, $\mathrm{n}$ & & 207 & 39 & 78 & 90 \\
\hline
\end{tabular}

ICS, Inhaled corticosteroid; LAMA, long-acting muscarinic antagonist; OCS, oral corticosteroid; PPI, proton-pump inhibitor. *Overlapping data. 
Table VII. Detection sensitivity and specificity of patient characteristics and time characteristics of cough in relation to disease.

\begin{tabular}{|c|c|c|c|c|c|c|c|c|c|c|c|c|c|}
\hline \multirow[b]{2}{*}{ Characteristic } & \multicolumn{13}{|c|}{ Disease } \\
\hline & Detection, \% & $\mathrm{BA}$ & CVA & $\mathrm{AC}$ & GERD & COPD & SBS & ARI & WC & PIC & $\mathrm{LC}$ & IP & $\mathrm{CC}$ \\
\hline \multicolumn{14}{|l|}{ Patient-related } \\
\hline \multirow[t]{2}{*}{ Age: $>65$ Years } & Sensitivity & 14 & 7 & 0 & 67 & 33 & 17 & 13 & 0 & 12 & 100 & 75 & 0 \\
\hline & Specificity & 83 & 83 & 84 & 85 & 84 & 84 & 83 & 84 & 82 & 85 & 85 & 84 \\
\hline \multirow[t]{2}{*}{ Gender: Male } & Sensitivity & 30 & 50 & 0 & 0 & 50 & 0 & 47 & 0 & 52 & 100 & 100 & 50 \\
\hline & Specificity & 51 & 54 & 53 & 53 & 54 & 52 & 54 & 53 & 57 & 54 & 55 & 54 \\
\hline \multirow[t]{2}{*}{ Smoking status: Ever/current } & Sensitivity & 37 & 29 & 50 & 0 & 100 & 0 & 38 & 0 & 33 & 100 & 100 & 50 \\
\hline & Specificity & 61 & 61 & 62 & 61 & 64 & 61 & 62 & 62 & 60 & 63 & 64 & 62 \\
\hline \multirow[t]{2}{*}{ With Pet } & Sensitivity & 17 & 21 & 50 & 33 & 33 & 17 & 27 & 0 & 20 & 50 & 17 & 50 \\
\hline & Specificity & 76 & 77 & 77 & 77 & 77 & 77 & 79 & 77 & 74 & 77 & 77 & 77 \\
\hline \multirow[t]{2}{*}{ Past history: Atopy } & Sensitivity & 47 & 21 & 100 & 33 & 33 & 33 & 27 & 0 & 27 & 0 & 33 & 50 \\
\hline & Specificity & 73 & 69 & 71 & 70 & 70 & 70 & 69 & 70 & 69 & 70 & 70 & 70 \\
\hline \multicolumn{14}{|l|}{ Time-related } \\
\hline \multirow[t]{2}{*}{ Daily variation } & Sensitivity & 53 & 29 & 100 & 0 & 0 & 67 & 44 & 0 & 35 & 50 & 33 & 0 \\
\hline & Specificity & 64 & 61 & 62 & 61 & 61 & 63 & 64 & 62 & 60 & 62 & 62 & 61 \\
\hline \multirow[t]{2}{*}{ Seasonal variation } & Sensitivity & 83 & 33 & 0 & 0 & 0 & 33 & 25 & 0 & 31 & 0 & 33 & 0 \\
\hline & Specificity & 87 & 77 & 76 & 75 & 76 & 77 & 77 & 76 & 78 & 76 & 77 & 76 \\
\hline
\end{tabular}

BA, Bronchial asthma; CVA, cough variant asthma; AC, atopic cough; GERD, gastro esophageal reflux disease; COPD, chronic obstructive lung disease; SBS, sinobronchial syndrome; ARI, acute respiratory infection; WC, whooping cough; PIC, post-infection cough; LC, lung cancer; IP, interstitial pneumonia; $\mathrm{CC}$, cardiogenic cough.

Hospital Research Ethics Committees of those hospitals. The results of our study were not directly disseminated to the study population. They will be presented locally in order to educate medical staff on our findings with the aim of changing practice to benefit our patients.

\section{Results}

Study participants. Demographics of the 418 patients are presented in Table I, which shows participants who developed cough regardless of age. There were slightly more females than males. Smoking status, having a pet, and the proportion of participants with atopy were similar to national statistics during the same period of time, and these results indicate that our data almost precisely represent the realworld data of patients with cough in Japan.

Time characteristics of cough. The time characteristics of cough, including daily variation, seasonal variation, and duration are summarized in Table II. In total, $40 \%$ of our participants had a cough which showed daily variation. Seasonal variation was observed in $19 \%$ of valid responses. More participants developed cough during the winter rather than the summer and almost $40 \%$ of participants had a chronic cough.

Complications of cough, including wheezing, sputum increase, pharyngeal discomfort, heartburn, anxiety, frustration, insomnia, and exertional dyspnea are summarized in Table III. Anxiety, frustration, and exertional dyspnea were less frequently observed complications of cough. An increase in sputum was the most commonly occurring complication of cough.
Triggers of cough, including talking, cigarette smoke, house dust, meals, and the common cold are summarized in Table IV. Our analysis showed that the common cold was the most common trigger of cough. On the other hand, mealinduced cough was only found in $10 \%$.

Diagnosis and treatment. Final diagnoses following treatment are summarized in Table V. When the duration of cough was long, the proportion of several primary diseases other than acute respiratory infection became greater. Efficacy rates for treatments are summarized in Table VI. $\beta_{2}$ Agonist or theophylline were effective in relieving cough in all patients with CVA. H1 blocker or inhaled corticosteroid were also effective in relieving cough in all patients with atopic cough.

Disease-specific features. To identify factors affecting diagnosis, sensitivity and specificity values were calculated from $2 \times 2$ contingency tables (Tables VII and VIII). Coughs in most patients with bronchial asthma had seasonal variation and were accompanied by wheezing. Patients with CVA and atopic cough did not have wheezing. Coughs in all patients with atopic cough were associated with a past history of atopy and daily variation; moreover, they were worsened by talking. All patients with GERD were female, suffered from heartburn, and their coughs showed no daily or seasonal variation. All patients with chronic obstructive lung disease (COPD), lung cancer (LC), and interstitial pneumonia had history of smoking 
Table VIII. Detection sensitivity and specificity of complications and triggers of cough in relation to disease.

\begin{tabular}{|c|c|c|c|c|c|c|c|c|c|c|c|c|c|}
\hline \multirow[b]{2}{*}{ Characteristic } & \multicolumn{13}{|c|}{ Disease } \\
\hline & Detection, $\%$ & BA & CVA & $\mathrm{AC}$ & GERD & COPD & SBS & ARI & WC & $\mathrm{PIC}$ & $\mathrm{LC}$ & IP & $\mathrm{CC}$ \\
\hline \multicolumn{14}{|l|}{ Complications of cough } \\
\hline \multirow[t]{2}{*}{ Wheezing } & Sensitivity & 70 & 0 & 0 & 33 & 50 & 0 & 14 & 0 & 23 & 0 & 0 & 50 \\
\hline & Specificity & 82 & 73 & 74 & 74 & 75 & 74 & 69 & 74 & 73 & 75 & 74 & 75 \\
\hline \multirow[t]{2}{*}{ Increase of sputum } & Sensitivity & 48 & 50 & 0 & 33 & 80 & 83 & 32 & 0 & 31 & 100 & 33 & 50 \\
\hline & Specificity & 63 & 62 & 61 & 61 & 62 & 62 & 58 & 61 & 57 & 62 & 61 & 61 \\
\hline \multirow[t]{2}{*}{ Pharyngeal discomfort } & Sensitivity & 21 & 29 & 0 & 3 & 17 & 0 & 22 & 0 & 17 & 0 & 0 & 50 \\
\hline & Specificity & 80 & 81 & 80 & 80 & 80 & 79 & 81 & 80 & 79 & 80 & 79 & 80 \\
\hline \multirow[t]{2}{*}{ Heartburn } & Sensitivity & 23 & 31 & 0 & 100 & 50 & 0 & 16 & 100 & 21 & 0 & 50 & 50 \\
\hline & Specificity & 77 & 78 & 77 & 78 & 78 & 77 & 74 & 78 & 76 & 77 & 78 & 78 \\
\hline \multirow[t]{2}{*}{ Anxiety } & Sensitivity & 28 & 43 & 50 & 67 & 17 & 50 & 9 & 0 & 10 & 50 & 0 & 100 \\
\hline & Specificity & 83 & 83 & 82 & 82 & 81 & 82 & 77 & 81 & 78 & 82 & 81 & 82 \\
\hline \multirow[t]{2}{*}{ Frustration } & Sensitivity & 19 & 7 & 50 & 67 & 33 & 33 & 12 & 0 & 9 & 50 & 0 & 50 \\
\hline & Specificity & 86 & 84 & 85 & 86 & 86 & 86 & 84 & 85 & 82 & 85 & 85 & 85 \\
\hline \multirow[t]{2}{*}{ Insomnia } & Sensitivity & 43 & 14 & 50 & 33 & 17 & 0 & 18 & 100 & 22 & 0 & 0 & 50 \\
\hline & Specificity & 80 & 76 & 77 & 77 & 77 & 76 & 74 & 77 & 76 & 76 & 76 & 77 \\
\hline \multirow[t]{2}{*}{ Exertional dyspnea } & Sensitivity & 21 & 0 & 50 & 33 & 17 & 0 & 13 & 0 & 12 & 0 & 17 & 100 \\
\hline & Specificity & 88 & 85 & 87 & 87 & 86 & 86 & 86 & 86 & 86 & 86 & 86 & 87 \\
\hline \multicolumn{14}{|l|}{ Triggers of cough } \\
\hline \multirow[t]{2}{*}{ Talking } & Sensitivity & 70 & 50 & 100 & 33 & 80 & 67 & 40 & 100 & 65 & 50 & 40 & 100 \\
\hline & Specificity & 45 & 41 & 43 & 41 & 43 & 43 & 35 & 42 & 46 & 42 & 42 & 43 \\
\hline \multirow[t]{2}{*}{ Cigarette smoke } & Sensitivity & 54 & 50 & 0 & 100 & 67 & 67 & 48 & 0 & 41 & 100 & 25 & 100 \\
\hline & Specificity & 67 & 66 & 65 & 66 & 66 & 66 & 69 & 65 & 68 & 66 & 65 & 66 \\
\hline \multirow[t]{2}{*}{ House dust } & Sensitivity & 79 & 88 & 50 & 100 & 100 & 33 & 63 & 0 & 58 & 100 & 20 & 0 \\
\hline & Specificity & 39 & 38 & 36 & 37 & 37 & 36 & 36 & 36 & 34 & 37 & 35 & 36 \\
\hline \multirow[t]{2}{*}{ Meal } & Sensitivity & 33 & 25 & 50 & 0 & 0 & 0 & 11 & 0 & 13 & 0 & 0 & 0 \\
\hline & Specificity & 87 & 84 & 84 & 83 & 83 & 83 & 81 & 84 & 80 & 83 & 83 & 84 \\
\hline \multirow[t]{2}{*}{ Common cold } & Sensitivity & 59 & 83 & 0 & 33 & 83 & 50 & 67 & 100 & 70 & 0 & 50 & 100 \\
\hline & Specificity & 33 & 36 & 34 & 34 & 35 & 34 & 49 & 35 & 37 & 34 & 34 & 35 \\
\hline
\end{tabular}

BA, Bronchial asthma; CVA, cough variant asthma; AC, atopic cough; GERD, gastro esophageal reflux disease; COPD, chronic obstructive lung disease; SBS, sinobronchial syndrome; ARI, acute respiratory infection; WC, whooping cough; PIC, post-infection cough; LC, lung cancer; IP, interstitial pneumonia; $\mathrm{CC}$, cardiogenic cough.

Table IX. Examples of questionnaires useful in the differential diagnosis of cough.

\begin{tabular}{ll}
\hline Diagnosis & Questionnaire \\
\hline $\begin{array}{l}\text { Bronchial asthma } \\
\text { Do you have wheezing with cough? }\end{array}$ & Do you have a seasonal change in cough? \\
$\begin{array}{l}\text { Atopic cough } \\
\text { Do you have a daily change in cough? }\end{array}$ & Do you have an atopic disease with cough? \\
$\begin{array}{l}\text { GERD } \\
\text { Sinobronchial syndrome }\end{array}$ & Do you have heartburn with cough? \\
$\begin{array}{l}\text { Whooping cough } \\
\text { Cardiogenic cough }\end{array}$ & $\begin{array}{l}\text { Does your sputum increase with cough? } \\
\text { Do you not sleep because of cough? }\end{array}$ \\
\hline
\end{tabular}

GERD, Gastro esophageal reflux disease.

tobacco. Coughs in patients with sinobronchial syndrome occurred only in females and were not associated with any complications, except for an increase of sputum. Patients with whooping cough were bothered by cough interrupting sleep and talking. All patients with cardiogenic cough had exertional dyspnea. Finally, patients with acute respiratory infection and post-infection cough had no defining characteristics. 


\section{Discussion}

This study investigated the detailed characteristics of patients who newly attended hospitals with any type of cough throughout a defined study period, and the clinical manifestations of their cough including duration, complications and triggers. The strength of our study is that we were able to include patients from all age groups and that many characteristics of the patients were similar to the national statistics during the same period of time. This means that our study precisely reflects the real-world setting of cough patients in Japan. We found that some of the patient characteristics, and the clinical manifestations of their cough, were useful in diagnosing the cause of cough. Table IX describes key questions which represent useful tools for the outpatients clinic. To the best of our knowledge, this is one of the largest multicenter studies to investigate the characteristics of Japanese patients with cough.

Previous studies relating to chronic cough often excluded patients with productive cough, abnormal chest $\mathrm{X}$ rays or abnormal spirometry (9-11). In contrast, in the present study, in order to avoid selection bias, we included patients with all types of cough, without any specific exclusion criteria. This may have increased the proportion of patients with cough caused by infection. Indeed, the present study showed a relatively high proportion of patients with acute respiratory infection (32\%) and post-infection cough (32\%) compared to previous studies (9-11). Moreover, it is difficult for clinicians to diagnose an increase of sputum. This is partly because, as a patient complaint, an increase of sputum is very subjective. In addition, purulent sputum is not always induced by bacterial infection (17). Therefore, it is difficult for clinicians to deal with patients without a productive cough.

In the current study, we first evaluated the potential use of patient characteristics and clinical manifestations when diagnosing the causes of cough (Tables VII and VIII). Our data showed that patient age (over 65 years) is an excellent diagnostic tool with high sensitivity and high specificity for patients with GERD, LC or interstitial pneumonia. Smoking status was also useful in diagnosing COPD, LC, or interstitial pneumonia. Smoking is well-established as the main risk factor for COPD, LC and idiopathic pulmonary fibrosis (1820 ). Indeed, about $90 \%$ of patients with COPD, LC, and 41$83 \%$ of patients with idiopathic pulmonary fibrosis had a history of smoking (21-23).

Our study showed that in patients with GERD, cough was accompanied by wheezing known to be specific to bronchial asthma, COPD or cardiogenic cough (Table VIII). However, it has been reported that patients with GERD often have wheezing (24). Therefore, clinicians should pay particular attention to cough with wheezing.

Triggers of cough, including talking, cigarette smoke, house dust, meals, and the common cold were shown to be less important in diagnosis. This is because a range of different diseases can cause cough due to these factors. This might be partly because sensitivity of the cough reflex is enhanced regardless of the cause in many patients. Cough reflex is mediated by two classes of sensory neurons which respond to mechanical stimuli and chemical stimuli such as capsaicin and bradykinin to varying degrees (25). Indeed, cough reflex sensitivity is enhanced in patients with several diseases (25-30). Therefore, clinicians should also pay special attention to the triggers of cough.

Our study has some limitations which need to be considered. Firstly, the proportion of patients with some underlying causes, for example CVA, atopic cough, and GERD, was small relative to the study population; this was mostly because in order to avoid selection bias, we included patients with all types of cough, without any specific exclusion criteria (Table V). However, a previous article also reported that these underlying causes only represent a small proportion of patients with cough (1), as reported for our current study cohort. This means that our study accurately represents the real-world data of patients with any type of cough who visit hospitals in Japan. Another limitation of our study is that CVA was underestimated because of the relatively small number of prescriptions of bronchodilators. It is believed that cough improves naturally in patients with CVA without the need for bronchodilators. Finally, our questionnaire did not include questions focused upon the nature of the sputum or some other triggers of cough such as perfume or working exposure.

In conclusion, described the underlying causes of cough in Japanese patients. Furthermore, our work identified clinical factors which represent useful tools for diagnosing the cause of cough. The results of our study might help clinicians diagnose the cause of cough in a more accurate manner, which would then lead to administration of an appropriate treatment. Further prospective studies are now needed to confirm the results of our study.

\section{Funding}

This research received no specific grant from any funding agency in the public, commercial or not-for-profit sectors.

\section{Competing Interest}

None declared.

\section{References}

1 Yamasaki A, Hanaki K, Tomita K, Watanabe M, Hasegawa Y, Okazaki R, Yamamura M, Fukutani K, Sugimoto Y, Kato K, Kodani M, Ikeda T, Konishi T, Kawasaki Y, Tokuyasu H, Yajima $\mathrm{H}$, Sejima H, Isobe T and Shimizu E: Cough and asthma diagnosis: physicians' diagnosis and treatment of patients complaining of acute, subacute and chronic cough in rural areas of Japan. Int J Gen Med 3: 101-107, 2010. 
2 Gibson PG and Vertigan AE: Management of chronic refractory cough. BMJ 351: h5590, 2015.

3 Dicpinigaitis PV, Tso $\mathrm{R}$ and Banauch G: Prevalence of depressive symptoms among patients with chronic cough. Chest 130: 1839-1843, 2006.

4 Kuzniar TJ, Morgenthaler TI, Afessa B and Lim KG: Chronic cough from the patient's perspective. Mayo Clin Proc 82: 56-60, 2007.

5 Kohno S, Ishida T, Uchida Y, Kishimoto H, Sasaki H, Shioya T, Tokuyama K, Niimi A, Nishi K, Fujimura M, Matsuse H and Suzaki H: The Japanese Respiratory Society guidelines for management of cough. Respirology 11: S135-186, 2006.

6 Kwon NH, Oh MJ, Min TH, Lee BJ and Choi DC: Causes and clinical features of subacute cough. Chest 129: 1142-1147, 2006.

7 Kang SY, Kim GW, Song WJ, Chang YS and Cho SH: Chronic cough in Korean adults: a literature review on common comorbidity. Asia Pac Allergy 6: 198-206, 2016.

8 Fujimura M, Abo M, Ogawa H, Nishi K, Kibe Y, Hirose T, Nakatsumi $\mathrm{Y}$ and Iwasa K: Importance of atopic cough, cough variant asthma and sinobronchial syndrome as causes of chronic cough in the Hokuriku area of Japan. Respirology 10: 201-207, 2005 .

9 Shirahata K, Fujimoto K, Arioka H, Shouda R, Kudo K and Ikeda S: Prevalence and clinical features of cough variant asthma in a general internal medicine outpatient clinic in Japan. Respirology 10: 354-358, 2005.

10 Matsumoto H, Niimi A, Takemura M, Ueda T, Yamaguchi M, Matsuoka H, Jinnai M, Chin K and Mishima M: Prevalence and clinical manifestations of gastro-oesophageal reflux-associated chronic cough in the Japanese population. Cough 3: 1, 2007.

11 Niimi A, Ohbayashi H, Sagara H, Yamauchi K, Akiyama K, Takahashi K, Inoue H, Wakayama T, Kobayashi H, Hasegawa M, Kimura G, Yokoe T and Adachi M: Cough variant and cough-predominant asthma are major causes of persistent cough: a multicenter study in Japan. J Asthma 50: 932-937, 2013.

12 McGarvey LP, Heaney LG, Lawson JT, Johnston BT, Scally CM, Ennis M, Shepherd DR and MacMahon J: Evaluation and outcome of patients with chronic non-productive cough using a comprehensive diagnostic protocol. Thorax 53: 738-743, 1998.

13 Niimi A, Amitani R, Suzuki K, Tanaka E, Murayama T and Kuze F: Eosinophilic inflammation in cough variant asthma. Eur Respir J 11: 1064-9, 1998.

14 Niimi A: Geography and cough aetiology. Pulm Pharmacol Ther 20: 383-387, 2007.

15 Fujimura M, Mizuguchi M, Nakatsumi Y, Mizuhashi K, Sasaki $\mathrm{S}$ and Yasui M: Addition of a 2-month low-dose course of levofloxacin to long-term erythromycin therapy in sinobronchial syndrome. Respirology 7: 317-324, 2002.

16 Fujimura M, Ogawa H, Nishizawa Y and Nishi K: Comparison of atopic cough with cough variant asthma: is atopic cough a precursor of asthma? Thorax 58: 14-18, 2003.
17 Gonzales R, Bartlett JG, Besser RE, Cooper RJ, Hickner JM, Hoffman JR and Sande MA: Principles of appropriate antibiotic use for treatment of uncomplicated acute bronchitis: background. Ann Intern Med 134: 521-529, 2001.

18 de Marco R, Accordini S, Marcon A, Cerveri I, Anto JM, Gislason T, Heinrich J, Janson C, Jarvis D, Kuenzli N, Leynaert B, Sunyer J, Svanes C, Wjst M and Burney P: Risk factors for chronic obstructive pulmonary disease in a European cohort of young adults. Am J Respir Crit Care Med 183: 891-897, 2011.

19 Satcher D: Cigars and public health. N Engl J Med 340: 1829$1831,1999$.

20 de Cremoux H, Bernaudin JF, Laurent P, Brochard P and Bignon $\mathrm{J}$ : Interactions between cigarette smoking and the natural history of idiopathic pulmonary fibrosis. Chest 98: 71-76, 1990.

21 Snider GL: Chronic obstructive pulmonary disease: risk factors, pathophysiology and pathogenesis. Annu Rev Med 40: 411-429, 1989.

22 Tyczynski JE, Bray F and Parkin DM: Lung cancer in Europe in 2000: epidemiology, prevention, and early detection. Lancet Oncol 4: 45-55, 2003.

23 Gasior G, Pierzchała W and Ograbek-Król M: The relationship between cigarette smoking and some types of idiopathic interstitial pneumonias. Wiad Lek 61: 48-52, 2008.

24 Zhang C, Wang ZG, Wu JM, Lai Y, Ji F, Gao X, Hu Z, Zhu G, Ning Y, Li Z, Liu H and Zhao J: A preliminary investigation of laparoscopic fundoplication treatment on gastroesophageal reflux disease-related respiratory symptoms. Surg Laparosc Endosc Percutan Tech 22: 406-409, 2012.

25 Vigeland CL, Hughes AH and Horton MR: Etiology and treatment of cough in idiopathic pulmonary fibrosis. Respir Med 123: 98-104, 2017.

26 Higenbottam T: Chronic cough and the cough reflex in common lung diseases. Pulm Pharmacol Ther 15: 241-247, 2002.

27 Kanemitsu Y, Matsumoto H, Osman N, Oguma T, Nagasaki T, Izuhara Y, Ito I, Tajiri T, Iwata T, Niimi A and Mishima M: "Cold air" and/or "talking" as cough triggers, a sign for the diagnosis of cough variant asthma. Respir Investig 54: 413-418, 2016.

28 Ohkura N, Hara J, Sakai T, Okazaki A, Abo M, Kasahara K and Fujimura M: Bronchoconstriction-triggered cough in atopic cough: A retrospective study. Exp Lung Res 42: 227-231, 2016.

29 Hennel M, Brozmanova M and Kollarik M: Cough reflex sensitization from esophagus and nose. Pulm Pharmacol Ther 35: 117-121, 2015.

30 Dicpinigaitis PV: Effect of viral upper respiratory tract infection on cough reflex sensitivity. J Thorac Dis 6: S708-711, 2014.

Received November 18, 2018

Revised December 5, 2018

Accepted December 10, 2018 